\title{
Generation of Nitric Acid and Nitrous Acid in Distilled Water Irradiated with Atmospheric-Pressure Plasma Jet
}

\author{
Hiroshi Kuwahata* \\ Department of Electrical and Electronics Engineering, School of Engineering, Tokai University, \\ 4-1-1 Kitakaname, Hiratsuka, Kanagawa 259-1292, Japan \\ Ikko Mikami \\ Department of Chemistry, School of Science, Tokai University, \\ 4-1-1 Kitakaname, Hiratsuka, Kanagawa 259-1292, Japan \\ (Received 20 August 2014; Accepted 1 September 2014; Published 20 September 2014)
}

\begin{abstract}
An atmospheric-pressure argon (Ar) plasma jet was directly irradiated onto distilled water. Semiquantitative determination using test strips and flow injection analysis (FIA) revealed that nitric acid $\left(\mathrm{HNO}_{3}\right)$ and nitrous acid $\left(\mathrm{HNO}_{2}\right)$ were generated in distilled water by plasma jet irradiation for $1 \mathrm{~min}$. The nitrate ion $\left(\mathrm{NO}_{3}{ }^{-}\right)$and nitrite ion $\left(\mathrm{NO}_{2}{ }^{-}\right)$concentrations in distilled water irradiated with a plasma jet, determined from the test strips, were in good agreement with those determined by FIA. The $\mathrm{NO}_{3}{ }^{-}$concentration in distilled water proportionally increased with the plasma irradiation time, whereas the $\mathrm{NO}_{2}{ }^{-}$concentration was almost unchanged. It is considered that high-energy electrons in the plasma jet collided with nitrogen molecules $\left(\mathrm{N}_{2}\right)$ and oxygen molecules $\left(\mathrm{O}_{2}\right)$ to generate nitrogen $(\mathrm{N})$ and oxygen $(\mathrm{O})$ radicals. Nitrogen oxide $\left(\mathrm{N}_{x} \mathrm{O}_{y}\right)$ generated upon the reaction of the radicals is considered to react with water molecules $\left(\mathrm{H}_{2} \mathrm{O}\right)$ in air and at the surface of distilled water to generate $\mathrm{HNO}_{3}$ and $\mathrm{HNO}_{2}$. [DOI: 10.1380/ejssnt.2014.410]
\end{abstract}

Keywords: Plasma processing; Water; Liquid surfaces; Nitric acid; Nitrous acid

\section{INTRODUCTION}

The decomposition of organic compounds in wastewater using discharges and plasmas is a popular area of research. For example, researchers have reported the decomposition of phenol [1-3], organic dyes [4, 5], and acetic acid (as a model of persistent organic substances) [6] in water using on-water pulse discharge and the decomposition of organic dyes $[7,8]$ in water using on-water atmospheric-pressure plasma.

Previously, we examined the decomposition of methylene blue, used as an organic dye, in distilled water using an atmospheric-pressure argon (Ar) plasma jet [9]. In that study, we carried out measurements by absorption spectroscopy and capillary electrophoresis and reported that (1) nitric acid $\left(\mathrm{HNO}_{3}\right)$ was generated in distilled water irradiated with an Ar plasma jet, (2) the generated nitrate ions $\left(\mathrm{NO}_{3}{ }^{-}\right)$contributed to a peak at a wavelength of approximately $200 \mathrm{~nm}$ in the absorbance spectrum, and (3) the $\mathrm{NO}_{3}{ }^{-}$concentration increased with the plasma irradiation time [10]. However, the estimated $\mathrm{NO}_{3}{ }^{-}$concentrations were not reported.

In this study, we found that nitrous acid $\left(\mathrm{HNO}_{2}\right)$, in addition to $\mathrm{HNO}_{3}$, was generated in distilled water irradiated with an atmospheric-pressure Ar plasma jet. The dependences of the $\mathrm{NO}_{3}{ }^{-}$and nitrite ion $\left(\mathrm{NO}_{2}{ }^{-}\right)$concentrations in distilled water on the plasma irradiation time were semiquantitatively determined using test strips and then quantitatively determined by flow injection analysis (FIA) based on absorption spectrophotometry using naphthyl ethylenediamine and a $\mathrm{Cu}-\mathrm{Cd}$ reduction column. The aim of this study is to clarify the phenomenon that always occurs when water is irradiated with an atmosphericpressure plasma jet regardless of the presence of organic compounds in the water.

\footnotetext{
* Corresponding author: kuwahata@keyaki.cc.u-tokai.ac.jp
}

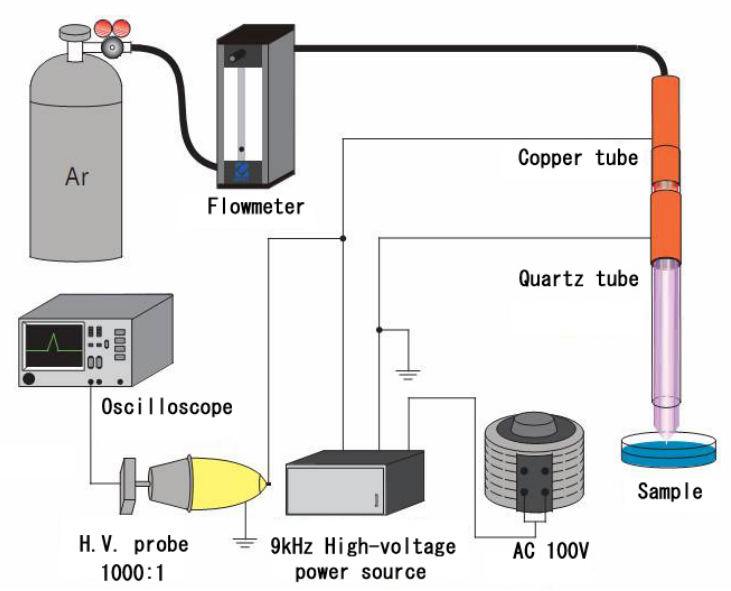

FIG. 1. Schematic of experimental setup.

\section{EXPERIMENTAL}

Figure 1 shows a schematic of the experimental setup used in this study. In this setup, a copper tube (inner diameter, $4 \mathrm{~mm}$; outer diameter, $6 \mathrm{~mm}$ ), used as a discharge electrode, is inserted into a dielectric quartz tube (length, $50 \mathrm{~mm}$; inner diameter, $6 \mathrm{~mm}$; outer diameter, $8 \mathrm{~mm}$ ), around which copper foil (thickness, $0.05 \mathrm{~mm}$; width, $10 \mathrm{~mm}$ ) is wrapped as a grounding electrode [11]. When a high $\mathrm{AC}$ voltage is applied, a dielectric barrier discharge is induced in the quartz tube between these electrodes, and the inflowing argon gas is excited to form a plasma that is then released into the atmosphere.

A plasma jet was generated at an Ar gas flow rate of $10 \mathrm{~L} / \mathrm{min}$ using a high-voltage power source (LHV-10AC, Logy Electric Co., Ltd.) with a frequency of $9 \mathrm{kHz}$ and an applied voltage of $10 \mathrm{kV}$. Under these conditions, the plasma jet extended approximately $30 \mathrm{~mm}$ from the end 


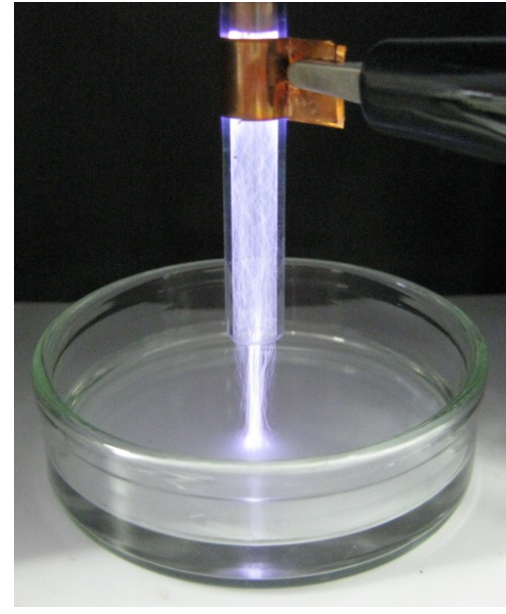

FIG. 2. Plasma jet irradiated onto distilled water.

of the quartz tube and its maximum diameter was approximately $6 \mathrm{~mm}[12]$.

Ten milliliters of distilled water (Wako Pure Chemical Industries, Ltd.) in a 60-mm-diameter glass Petri dish was directly irradiated with an atmospheric-pressure Ar plasma jet for $1-30 \mathrm{~min}$. The distance between the end of the quartz tube and the surface of the distilled water was approximately $15 \mathrm{~mm}$.

To confirm the generation of $\mathrm{NO}_{3}{ }^{-}$and $\mathrm{NO}_{2}{ }^{-}$in distilled water, the following two methods were adopted. First, the $\mathrm{NO}_{3}{ }^{-}$and $\mathrm{NO}_{2}{ }^{-}$concentrations were semiquantitatively determined using test strips (Quantofix Nitrate Nitrite, Macherey-Nagel GmbH \& Co. KG). These test strips can be used to semiquantitatively determine the $\mathrm{NO}_{3}{ }^{-}$and $\mathrm{NO}_{2}{ }^{-}$concentrations on the basis of the color change of the reagent-containing test strips $\left(5 \times 5 \mathrm{~mm}^{2}\right)$. Each test strip was immersed for $1 \mathrm{~s}$ in distilled water irradiated with a plasma jet and the $\mathrm{NO}_{3}{ }^{-}$ and $\mathrm{NO}_{2}{ }^{-}$concentrations were determined from the resulting color. For each concentration, the average of three measurements was used.

Next, the $\mathrm{NO}_{3}{ }^{-}$and $\mathrm{NO}_{2}{ }^{-}$concentrations were determined by FIA. Two transfer pumps (DP-8020, Tosoh Corporation; PU-2080, JASCO Corporation) and a detector (UV-2075, JASCO Corporation) were used. Naphthyl ethylenediamine absorption spectrophotometry (detection wavelength, $530 \mathrm{~nm}$ ) was used to detect $\mathrm{NO}_{2}{ }^{-}$. $\mathrm{NO}_{3}{ }^{-}$was reduced to $\mathrm{NO}_{2}{ }^{-}$using a $\mathrm{Cu}-\mathrm{Cd}$ reduction column and detected similarly by absorption spectrophotometry. The $\mathrm{NO}_{3}{ }^{-}$concentration was calculated by subtracting the $\mathrm{NO}_{2}{ }^{-}$concentration calculated using the absorbance obtained before the reduction from the $\mathrm{NO}_{2}{ }^{-}$ concentration after the reduction.

\section{RESULTS AND DISCUSSION}

Figure 2 shows a plasma jet irradiated onto distilled water. Streamer discharges are generated in the plasma jet and appear to reach the surface of the distilled water.

Figure 3 shows the color charts of the test strips and the changes in color of the $\mathrm{NO}_{3}{ }^{-}$and $\mathrm{NO}_{2}{ }^{-}$test strips immersed in distilled water irradiated with the plasma jet.
The test strips remained white before plasma jet irradiation, meaning that $\mathrm{NO}_{3}{ }^{-}$and $\mathrm{NO}_{2}{ }^{-}$were not present in the distilled water before plasma jet irradiation. The test strips became light pink after 1 min of irradiation, and the pink color darkened with increasing plasma irradiation time. These results indicate that $\mathrm{NO}_{3}{ }^{-}$and $\mathrm{NO}_{2}{ }^{-}$were generated in distilled water irradiated with the plasma jet for $1 \mathrm{~min}$ and that their concentrations increased with the plasma irradiation time.

Figure 4 shows the dependences of the $\mathrm{NO}_{3}{ }^{-}$and $\mathrm{NO}_{2}{ }^{-}$ concentrations in distilled water on the plasma irradiation time determined from the color changes of the test strips. The $\mathrm{NO}_{3}{ }^{-}$concentration was $0 \mathrm{mg} / \mathrm{L}$ before plasma jet irradiation and proportionally increased with the plasma irradiation time: it was approximately $5 \mathrm{mg} / \mathrm{L}$ after $1 \mathrm{~min}$ of irradiation, $10 \mathrm{mg} / \mathrm{L}$ after $3 \mathrm{~min}$ of irradiation, $20 \mathrm{mg} / \mathrm{L}$ after $5 \mathrm{~min}$ of irradiation, $30 \mathrm{mg} / \mathrm{L}$ after $10 \mathrm{~min}$ of irradiation, $40 \mathrm{mg} / \mathrm{L}$ after $15 \mathrm{~min}$ of irradiation, $50 \mathrm{mg} / \mathrm{L}$ after $20 \mathrm{~min}$ of irradiation, and $70 \mathrm{mg} / \mathrm{L}$ after $30 \mathrm{~min}$ of irradiation. The $\mathrm{NO}_{2}{ }^{-}$concentration was $0 \mathrm{mg} / \mathrm{L}$ before plasma jet irradiation and increased with the plasma irradiation time up to $15 \mathrm{~min}$. However, it decreased when the plasma irradiation time exceeded $15 \mathrm{~min}$ : it was approximately $1 \mathrm{mg} / \mathrm{L}$ after $1 \mathrm{~min}$ of irradiation, $3 \mathrm{mg} / \mathrm{L}$ after $3 \mathrm{~min}$ of irradiation, $5 \mathrm{mg} / \mathrm{L}$ after $5 \mathrm{~min}$ of irradiation, $7 \mathrm{mg} / \mathrm{L}$ after $10 \mathrm{~min}$ of irradiation, $10 \mathrm{mg} / \mathrm{L}$ after $15 \mathrm{~min}$ of irradiation, $7 \mathrm{mg} / \mathrm{L}$ after $20 \mathrm{~min}$ of irradiation, and $7 \mathrm{mg} / \mathrm{L}$ after $30 \mathrm{~min}$ of irradiation. These values were obtained by semiquantitative determination.

FIA was carried out to quantitatively determine the $\mathrm{NO}_{3}{ }^{-}$and $\mathrm{NO}_{2}{ }^{-}$concentrations. Figure 5 shows the dependences of the $\mathrm{NO}_{3}{ }^{-}$and $\mathrm{NO}_{2}{ }^{-}$concentrations in distilled water on the plasma irradiation time, as determined by FIA. The $\mathrm{NO}_{3}{ }^{-}$concentration was $0 \mathrm{mg} / \mathrm{L}$ before plasma jet irradiation and proportionally increased with the plasma irradiation time: it was $2.0 \mathrm{mg} / \mathrm{L}$ after $1 \mathrm{~min}$ of irradiation, $8.2 \mathrm{mg} / \mathrm{L}$ after $5 \mathrm{~min}$ of irradiation, $18.1 \mathrm{mg} / \mathrm{L}$ after $10 \mathrm{~min}$ of irradiation, $42.6 \mathrm{mg} / \mathrm{L}$ after $20 \mathrm{~min}$ of irradiation, and $76.5 \mathrm{mg} / \mathrm{L}$ after $30 \mathrm{~min}$ of irradiation. The $\mathrm{NO}_{2}{ }^{-}$concentration was $0 \mathrm{mg} / \mathrm{L}$ before plasma jet irradiation and increased with the plasma irradiation time up to $10 \mathrm{~min}$. However, it decreased when the plasma irradiation time exceeded $10 \mathrm{~min}$ : it was $1.0 \mathrm{mg} / \mathrm{L}$ after $1 \mathrm{~min}$ of irradiation, $2.61 \mathrm{mg} / \mathrm{L}$ after $5 \mathrm{~min}$ of irradiation, $3.75 \mathrm{mg} / \mathrm{L}$ after $10 \mathrm{~min}$ of irradiation, $2.13 \mathrm{mg} / \mathrm{L}$ after $20 \mathrm{~min}$ of irradiation, and $0.61 \mathrm{mg} / \mathrm{L}$ after $30 \mathrm{~min}$ of irradiation. These results were in good agreement with the results obtained using the test strips.

Watanabe performed ion chromatography measurements of the concentration of negative ions generated in pure water subjected to a silent discharge. According to his report, $\mathrm{NO}_{3}{ }^{-}$was present but little $\mathrm{NO}_{2}{ }^{-}$was present in pure water after the discharge. Moreover, the $\mathrm{NO}_{3}{ }^{-}$ concentration linearly increased with the discharge time [13]. However, the estimated $\mathrm{NO}_{3}{ }^{-}$concentrations were not reported.

Ikawa et al. reported that $\mathrm{NO}_{3}{ }^{-}$and $\mathrm{NO}_{2}{ }^{-}$were generated in distilled water irradiated with an atmosphericpressure helium (He) plasma jet and that the $\mathrm{NO}_{3}{ }^{-}+$ $\mathrm{NO}_{2}{ }^{-}$concentration proportionally increased with the plasma irradiation time on the basis of the results of ion chromatography [14]. Their results were in good agreement with our results. However, they did not separately 


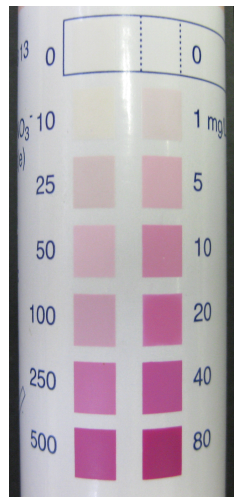

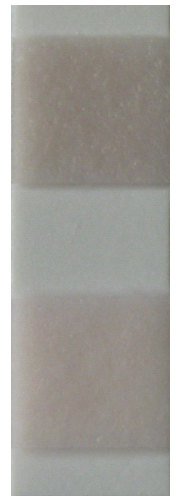

(a)

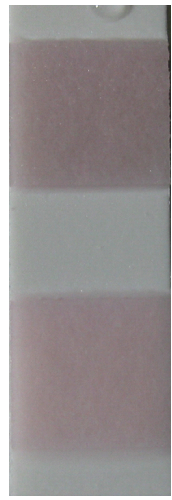

(b)

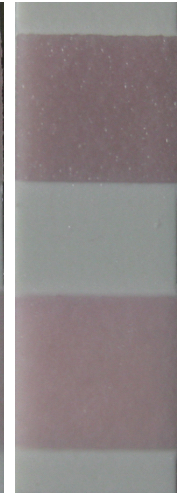

(c)

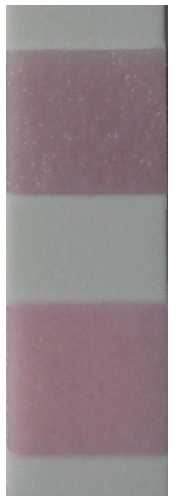

(d)

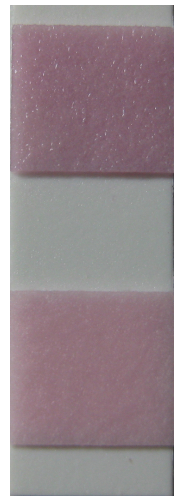

(e)

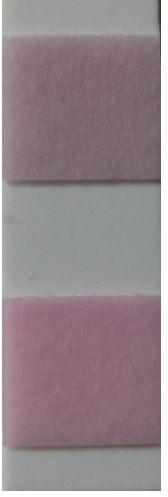

(f)

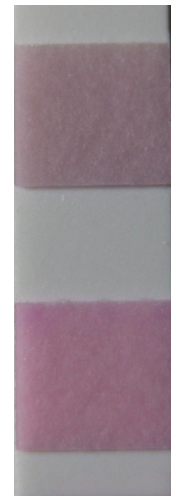

(g)

FIG. 3. Color charts of test strips and changes in color of test strips immersed in plasma-jet-irradiated distilled water (Color chart: left, $\mathrm{NO}_{3}{ }^{-}$; right, $\mathrm{NO}_{2}{ }^{-}$. Test strip: top, $\mathrm{NO}_{2}{ }^{-}$; bottom, $\mathrm{NO}_{3}{ }^{-}$). (a) After 1 min of irradiation, (b) after 3 min of irradiation, (c) after 5 min of irradiation, (d) after 10 min of irradiation, (e) after 15 min of irradiation, (f) after 20 min of irradiation, and $(\mathrm{g})$ after $30 \mathrm{~min}$ of irradiation.

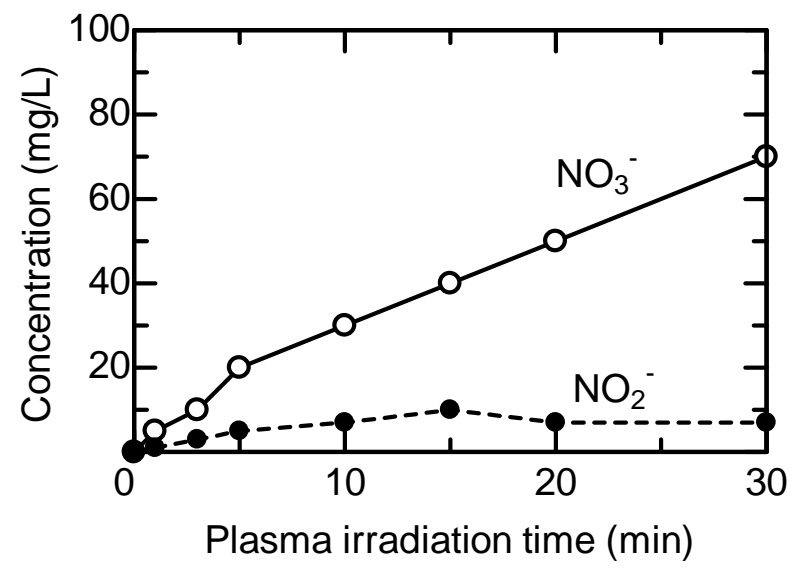

FIG. 4. Dependences of $\mathrm{NO}_{3}{ }^{-}$and $\mathrm{NO}_{2}{ }^{-}$concentrations in distilled water on plasma irradiation time determined from color changes of test strips.

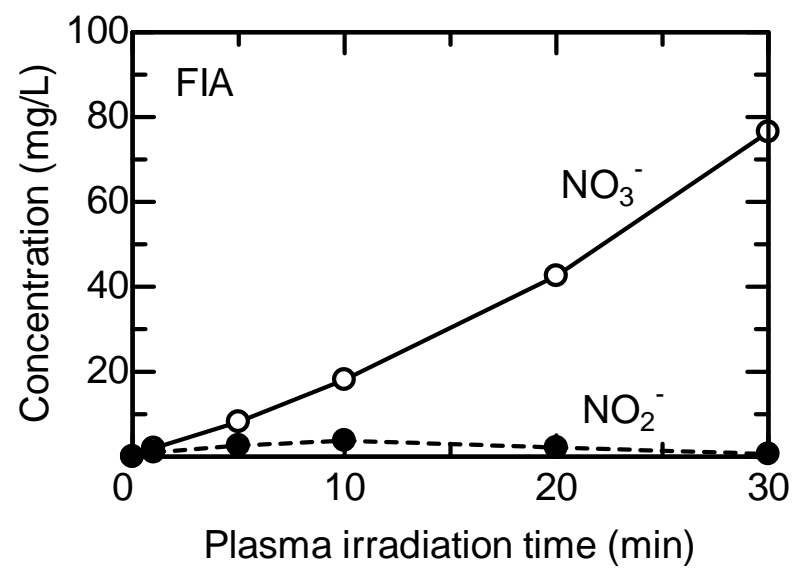

FIG. 5. Dependences of $\mathrm{NO}_{3}{ }^{-}$and $\mathrm{NO}_{2}{ }^{-}$concentrations in distilled water on plasma irradiation time determined by FIA. determine the $\mathrm{NO}_{3}{ }^{-}$and $\mathrm{NO}_{2}{ }^{-}$concentrations.

From the results of ion chromatography, Huang et al. reported that $\mathrm{NO}_{3}{ }^{-}$was generated in pure water subjected to dielectric-barrier discharge and that the $\mathrm{NO}_{3}{ }^{-}$ concentration increased with the discharge time [8]. However, no estimated $\mathrm{NO}_{3}{ }^{-}$concentrations were reported.

During atmospheric discharge, the following reactions occur [15-17].

$$
\begin{aligned}
\mathrm{N}_{2}+\mathrm{e} & \rightarrow 2 \mathrm{~N}+\mathrm{e} \\
\mathrm{O}_{2}+\mathrm{e} & \rightarrow 2 \mathrm{O}+\mathrm{e} \\
\mathrm{O}+\mathrm{O}_{2}+\mathrm{M} & \rightarrow \mathrm{O}_{3}+\mathrm{M} \\
\mathrm{N}+\mathrm{O}_{2} & \rightarrow \mathrm{NO}+\mathrm{O} \\
\mathrm{NO}+\mathrm{O} & \rightarrow \mathrm{NO}_{2} \\
\mathrm{NO}+\mathrm{O}_{3} & \rightarrow \mathrm{NO}_{2}+\mathrm{O}_{2} \\
\mathrm{NO}_{2}+\mathrm{N} & \rightarrow \mathrm{N}_{2} \mathrm{O}+\mathrm{O} \\
\mathrm{NO}_{2}+\mathrm{O} & \rightarrow \mathrm{NO}_{3} \\
\mathrm{NO}_{2}+\mathrm{O} & \rightarrow \mathrm{NO}_{3}+\mathrm{O}_{2} \\
\mathrm{NO}_{2}+\mathrm{NO} & \rightarrow \mathrm{N}_{2} \mathrm{O}_{3} \\
\mathrm{NO}_{2}+\mathrm{NO}_{3}+\mathrm{M} & \rightarrow \mathrm{N}_{2} \mathrm{O}_{5}+\mathrm{M} \\
\mathrm{N}_{2} \mathrm{O}_{5}+\mathrm{H}_{2} \mathrm{O} & \rightarrow 2 \mathrm{HNO}_{3} \\
\mathrm{~N}_{2} \mathrm{O}_{3}+\mathrm{H}_{2} \mathrm{O} & \rightarrow 2 \mathrm{HNO}_{2}
\end{aligned}
$$

Electrons (e) collide with nitrogen molecules $\left(\mathrm{N}_{2}\right)$ and oxygen molecules $\left(\mathrm{O}_{2}\right)$ in air to generate nitrogen $(\mathrm{N})$ and oxygen $(\mathrm{O})$ radicals. The $\mathrm{O}$ radicals react with $\mathrm{O}_{2}$ to generate ozone $\left(\mathrm{O}_{3}\right)$. Through these reactions, nitrogen oxide $\left(\mathrm{N}_{x} \mathrm{O}_{y}\right)$ is generated. Dinitrogen pentoxide $\left(\mathrm{N}_{2} \mathrm{O}_{5}\right)$ and dinitrogen trioxide $\left(\mathrm{N}_{2} \mathrm{O}_{3}\right)$ react with water molecules $\left(\mathrm{H}_{2} \mathrm{O}\right)$ in air to generate $\mathrm{HNO}_{3}$ and $\mathrm{HNO}_{2}$, respectively. Here, $\mathrm{M}$ is called the third body and absorbs the internal energy of the generated molecules to stabilize them and prevent their dissociation.

Braun et al. confirmed that $\mathrm{O}_{3}, \mathrm{~N}_{2} \mathrm{O}, \mathrm{N}_{2} \mathrm{O}_{5}$, and $\mathrm{HNO}_{3}$ were generated in air by atmospheric discharge [15]. Miyazaki et al. found, using a gas detector, that 
$\mathrm{O}_{3}$, $\mathrm{NO}$, and $\mathrm{NO}_{2}$ were generated in a $\mathrm{N}_{2}-\mathrm{O}_{2}$ gas mixture upon pulse discharge [4]. Chen et al. reported that $\mathrm{O}_{3}$, $\mathrm{NO}$, and $\mathrm{NO}_{2}$ were generated in air by atmospheric dielectric-barrier discharge. They also reported that the $\mathrm{NO}_{2}$ concentration increased with the discharge time whereas the NO concentration was almost unchanged [18].

Similar reactions are considered to occur during plasma jet irradiation in air. In addition to the reactions with $\mathrm{H}_{2} \mathrm{O}$ in air [reactions (12) and (13)], a reaction with $\mathrm{H}_{2} \mathrm{O}$ at the surface of the distilled water may have occurred in our experiment. Therefore, we consider that $\mathrm{HNO}_{3}$ and $\mathrm{HNO}_{2}$ were generated in distilled water and ionized to $\mathrm{H}^{+}$and $\mathrm{NO}_{3}{ }^{-}$[reaction (14)] and $\mathrm{H}^{+}$and $\mathrm{NO}_{2}{ }^{-}$[reaction (15)], respectively.

$$
\begin{aligned}
& \mathrm{HNO}_{3} \rightarrow \mathrm{H}^{+}+\mathrm{NO}_{3}^{-} \\
& \mathrm{HNO}_{2} \rightarrow \mathrm{N}^{+}+\mathrm{NO}_{2}^{-}
\end{aligned}
$$

\section{CONCLUSIONS}

An experiment using test strips and FIA based on absorption spectrophotometry using naphthyl ethylenediamine and a $\mathrm{Cu}-\mathrm{Cd}$ reduction column revealed that $\mathrm{HNO}_{3}$ and $\mathrm{HNO}_{2}$ were generated and ionized in distilled water irradiated with an atmospheric-pressure Ar plasma jet. The $\mathrm{NO}_{3}{ }^{-}$and $\mathrm{NO}_{2}{ }^{-}$concentrations in distilled water irradiated with a plasma jet determined from the test strips were in good agreement with those determined by FIA.

The $\mathrm{NO}_{3}{ }^{-}$concentration in distilled water proportionally increased with the plasma irradiation time, whereas the $\mathrm{NO}_{2}{ }^{-}$concentration was almost unchanged. The $\mathrm{NO}_{3}{ }^{-}$and $\mathrm{NO}_{2}{ }^{-}$concentrations in distilled water irradiated with an Ar plasma jet for 30 min were 76.5 and $0.61 \mathrm{mg} / \mathrm{L}$, respectively.

High-energy electrons in the plasma jet collided with $\mathrm{N}_{2}$ and $\mathrm{O}_{2}$ in air to generate $\mathrm{N}$ and $\mathrm{O}$ radicals. They reacted and produced $\mathrm{N}_{x} \mathrm{O}_{y} \cdot \mathrm{HNO}_{3}$ and $\mathrm{HNO}_{2}$ are considered to be generated upon the reaction of $\mathrm{N}_{x} \mathrm{O}_{y}$ with $\mathrm{H}_{2} \mathrm{O}$ in air and at the surface of distilled water.

\section{ACKNOWLEDGMENTS}

From the above discussion, $\mathrm{NO}_{3}{ }^{-}$and $\mathrm{NO}_{2}{ }^{-}$are considered to be generated in distilled water irradiated with a plasma jet.
The authors are grateful to Professor R. Ohyama of Tokai University for his valuable advice.
[1] A. K. Sharama, B. R. Locke, P. Arce, and W. C. Finney, Hazard. Waste Hazard. Mater. 10, 209 (1993).

[2] W. F. L. M. Hoeben, E. M. Van Veldhuizen, W. R. Rutgers, and G. M. W. Kroesen, J. Phys. D: Appl. Phys. 32, L-133 (1999).

[3] T. Kuroki, K. Yoshida, H. Watanabe, M. Okubo, and T. Yamanoto, Jpn. J. Appl. Phys. 45, 4296 (2006).

[4] Y. Miyazaki, K. Satoh, and H. Itoh, IEEJ Trans. Fundam. Mater. 128, 172 (2008) [in Japanese].

[5] S. Ikoma, K. Satoh, and H. Itoh, IEEJ Trans. Fundam. Mater. 129, 237 (2009) [in Japanese].

[6] T. Miichi, T. Fujimoto, and T. Takeda, IEEJ Trans. Fundam. Mater. 131, 853 (2011) [in Japanese].

[7] K. Kitano, H. Aoki, and S. Hamaguchi, Jpn. J. Appl. Phys. 45, 8294 (2006).

[8] F. Huang, L. Chen, H. Wang, and Z. Yan, Chem. Eng. J. 162, 250 (2010)

[9] H. Kuwahata, K. Kimura, and R. Ohyama, e-J. Surf. Sci. Nanotech. 8, 381 (2010).
[10] H. Kuwahata, K. Kimura, and I. Mikami, e-J. Surf. Sci. Nanotech. 9, 442 (2011).

[11] R. Ohyama and A. Nagai, Japan Patent 244938 (2006).

[12] H. Kuwahata and R. Ohyama, Hyomen Kagaku 30, 174 (2009) [in Japanese].

[13] T. Watanabe, J. Plasma Fusion Res. 75, 651 (1999) [in Japanese].

[14] S. Ikawa, K. Kitano, and S. Hamaguchi, Plasma Process. Polym. 7, 33 (2010).

[15] D. Braun, U. Kuchler, and G. Pietsch, Pure Appl. Chem. 60, 741 (1988).

[16] S. Mukkavilli, C. K. Lee, K. Varghese, and L. L. Tavlarides, IEEE Trans. Plasma Sci. 16, 652 (1988).

[17] J. S. Chang, P. A. Lawless, and T. Yamamoto, IEEE Trans. Plasma Sci. 19, 1152 (1991).

[18] G. Chen, M. Zhou, S. Chen, and W. Chen, J. Hazard. Mater. 172, 786 (2009). 